\title{
New information on the pterosaur Tupandactylus imperator, with comments on the relationships of Tapejaridae
}

Felipe L. Pinheiro, Daniel C. Fortier, Cesar L. Schultz, José Artur F.G. De Andrade, and Renan A.M. Bantim

Acta Palaeontologica Polonica 56 (3), 2011: 567-580 doi: http://dx.doi.org/10.4202/app.2010.0057

A new specimen of Tupandactylus imperator, comprising an incomplete skull with associated lower jaw, is described. The material is the best preserved specimen of this species known so far and provides new information on the anatomy of this pterodactyloid pterosaur, especially with respect to the morphology of the lower jaw, the first one formally described for the species. Also, the new specimen shows an extensive preservation of soft tissues such as the soft-tissue component of the headcrest, ramphoteca associated with the premaxillae and lower jaw, as well as probable pycnofibres. Aphylogenetic analysis was performed in order to test the relationships of the taxon within Tapejaridae. The results of the analysis support Tapejaridae, as well as monophyly of Tapejarinae and Thalassodrominae.

Key words: Pterosauria, Tapejaridae, Tupandactylus imperator, phylogeny, Crato Formation, Brazil.

Felipe L. Pinheiro [fl_pinheiro@yahoo.com.br], Daniel C. Fortier [danielcfortier@yahoo.com.br ] and Cesar L. Schultz [cesar.shultz@ufrgs.br], Universidade Federal do Rio Grande do Sul, Setor de Paleovertebrados, Av. Bento Gonçalves, 9500 Bloco J, Prédio 43127, Campus do Vale, Agronomia - Porto Alegre, Rio Grande do Sul, Brasil. CEP: 91509-900; José Artur F. G. de Andrade [artur.andrade@ dnpm.gov.br ], Centro de Pesquisas Paleontológicas da Chapada do Araripe, Departamento Nacional de Produção Mineral, Praça da Sé, 105 - Crato, Ceará, Brasil. CEP: 633100-440; Renan A. M. Bantim [bantim.ram@gmail.com], Universidade Regional do Cariri, Laboratório de Paleontologia, Rua Cel. Antônio Luis, 1161, Pimenta - Crato, Ceará, Brasil. CEP: 63100-000.

This is an open-access article distributed under the terms of the Creative Commons Attribution License (for details please see creativecommons.org), which permits unrestricted use, distribution, and reproduction in any medium, provided the original author and source are credited. 
Farf Full text $(1,970.5 \mathrm{kB})$ 